http://dx.doi.org/10.11646/phytotaxa.97.2.2

\title{
Notes on Early Land Plants Today. 35. Notes on Lophoziaceae (Marchantiophyta)
}

\author{
L. SÖDERSTRÖM ${ }^{1}$, JIŘÍ VÁŇA², ANDERS HAGBORG ${ }^{3} \&$ MATT VON KONRAT $^{3}$ \\ ${ }^{1}$ Department of Biology, Norwegian University of Science and Technology, N-7491 Trondheim, Norway; lars.soderstrom@bio.ntnu.no \\ ${ }^{2}$ Department of Botany, Charles University, Benátská 2, CZ-12801 Praha 2, Czech Republic; vana@natur.cuni.cz \\ ${ }^{3}$ Department of Botany, The Field Museum, 1400 South Lake Shore Drive, Chicago, IL 60605-2496, USA; hagborg@pobox.com, \\ mvonkonrat@fieldmuseum.org
}

\begin{abstract}
Recent redefinition of Lophoziaceae has led to many nomenclature and taxonomic changes but several problems remains. Here we discuss and make the necessary new combinations for Lophoziopsis longidens subsp. arctica, Lophoziopsis pellucida var. minor, Heterogemma patagonica and Trilophozia quinquedentata var. asymetrica. A number of new synonyms are proposed. Lophozia handelii is shown to be a synonym to Lophozia pallida and the species is treated separate from Lophozia guttulata. Four problematic names in Lophozia (Lophozia groenlandica, Lophozia murmanica, Lophozia confertifolia and Lophozia longiflora) are discussed and a conspectus of the genus is given.
\end{abstract}

\section{Introduction}

The definition of Lophoziaceae Cavers (1910: 293) as a family has changed dramatically in recent years based on molecular studies. Schill et al. (2004) included the whole family as defined by Schuster (1969) in Scapaniaceae Migula (1904: 479). De Roo et al. (2007) showed that it included several unrelated groups. It has later been separated into Anastrophyllaceae Söderström et al. (2010: 48), Scapaniaceae, Jamesoniellaceae He-Nygrén et al. (2006: 27) and Lophoziaceae, as well as moving Leiocolea (Müller 1913: 711) Buch (1933: 288) to Jungermanniaceae Reichenbach (1828). Even so, the family still includes elements that should be removed.

The genus Lophozia (Dumortier 1831: 53) Dumortier (1835: 17) as defined by Schuster (1969) is also shown to be very heterogeneous and the species belong to at least 4 families (De Roo et al. 2007). The breakup of the genus has resulted in several new names and combinations (Söderström et al. 2010, Konstantinova \& Vilnet 2010) but a few taxa remain to be transferred or synonymized.

The format of this note follows Söderström et al. (2012) except that we use the Melbourne International Code of Nomenclature for algae, fungi, and plants (ICN; McNeill et al. 2012) instead of the Vienna International Botanical Code of Nomenclature (ICBN; McNeill et al. 2006).

\section{New combinations and new synonyms in Lophoziopsis Konstant. et Vilnet}

Lophoziopsis Konstantinova \& Vilnet (2010: 66) was established for the majority of the Lophozia s.lat. with red gemmae. However, a few taxa remain to be transferred.

Lophozia nepalensis was described by Bakalin (2003: 50) from Nepal based on a specimen collected by Josef Poelt in 1962. The characters separating it from Lophoziopsis longidens were 1) acute-lobed leaves with angulate sinus vs. more or less hornlike lobes and U-shaped sinus, 2) concentration of gemmae (purple, not 
red-brown) in apical leaves, not on lobe tips, 3) funnel-like base of the leaves, which are loosely canaliculateconduplicate vs. almost transversely inserted and decurved in Lophoziopsis longidens, and 4) presence of attenuate shoot apices. One of us (JV) could examine rich material from Himalaya collected by David Long and found 2-3 specimens with more or less attenuate shoot apices. Of the characters given by Bakalin, character 1 (acute-lobed leaves) and 3 (funnel-like leaf bases) are of no value as both characters can be found also in some specimens of Lophoziopsis longidens, and character 2 (concentration of gemmae) is not constant and mostly refers to attenuate shoot apices. We interpret Lophozia nepalensis as a modification of Lophoziopsis longidens with attenuate apices induced by ecological conditions.

Lophoziopsis excisa (Dicks.) Konstant. et Vilnet, Arctoa 18: 66, 2009 [2010] (Konstantinova \& Vilnet 2010). Basionym:- Jungermannia excisa Dicks., Fasc. Pl. Crypt. Brit. 3: 11, 1793 (Dickson 1793).

= Lophozia excisa var. gemmicumulata Bakalin, Monogr. Lophozia: 99, 2005 (Bakalin 2005), syn. nov. Type:GERMANY. Sachsen: Vogtland, zwischen Schneckenstein und Winselburg. 11 August 1917, M. Spindler. Schiffner, Hepaticae europaeae N. 1398 (holotype KPABG). ELophozia cylindracea var. gemmicumulata Spindl. ex Schiffn., Krit. Bemerk. Eur. Lebermoose 28: 29, 1942 (Schiffner 1942), nom. inval. (ICN Art. 39.1; no Latin description).

Lophoziopsis longidens (Lindb.) Konstant. et Vilnet, Arctoa 18: 66, 2009 [2010] (Konstantinova \& Vilnet 2010).

Basionym:- Jungermannia longidens Lindb., Helsingfors Dagblad 1876 (323): 2 (Lindberg 1876).

= Lophozia nepalensis Bakalin, Ann. Bot. Fenn. 40: 50, 2003 (Bakalin 2003), syn. nov. Type:-NEPAL. East Nepal: Vorhimalaya, Abies-Rhododendron forest, on decaying wood, 1962 Poelt H214, (holotype JE!).

Lophoziopsis longidens subsp. arctica (R.M.Schust.) Váňa et L.Söderstr., comb. nov.

Basionym:-Lophozia longidens subsp. arctica R.M.Schust., Hepat. Anthocerotae N. Amer. 2: 539, 1969 (Schuster 1969).

Type:-GREENLAND. Kânâk, Red Cliff Peninsula, NW. Greenland, in deep, vertical dry cleft formation bedrock by ice action, plateau between coastal hills and ice cap, 1500-1600 feet, 4 miles northwest of village, Schuster RMS 45649 (holotype F-2142374).

$\equiv$ Lophozia longidens var. arctica (R.M.Schust.) Schljakov, Petjen. Mchi Sev. SSSR 3: 108, 1980 (Schljakov 1980).

$\equiv$ Lophozia pellucida f. arctica (R.M.Schust.) Bakalin, Monogr. Lophozia: 112 (Bakalin 2005).

$\equiv$ Lophoziopsis rubrigemma f. arctica (R.M.Schust.) Bakalin, Arctoa 18: 38, 2009 [2010] (Konstantinova et al. 2010).

Lophoziopsis pellucida var. minor (R.M.Schust.) L.Söderstr. et Váňa, comb. nov.

Basionym:-Lophozia pellucida var. minor R.M.Schust., Canad. J. Bot. 39: 984, 1961 (Schuster 1961c).

Type:-CANADA. Nunavut: Damp, weakly basic steep slope, south end of Hilgar Bay, $82^{\circ} 26^{\prime} \mathrm{N}, 63^{\circ} 25^{\prime} \mathrm{W}$, northeast Ellesmere I, Schuster RMS 35237 (holotype F).

\section{The identity of Lophozia patagonica}

Lophozia patagonica was described as belonging to sect. Heterogemma Jørgensen (1934: 146) but “may likely prove to be a synonym of Lophozia capitata" (=Heterogemma capitata (Hooker 1816: pl. 80) Konstantinova \& Vilnet (2010: 67)) according to Schuster (2002). Although the type lacks gemmae, the placement in Heterogemma (Jørg.) Konstantinova \& Vilnet (2010: 67) can be confirmed. The dorsal cortical cells are more than 4x longer than wide and leaf cells are large. In addition, Schäfer-Verwimp (1996) found gemmae similar to species in Heterogemma in a specimen identified as the current species. He was also able to study living plants from Brazil and discussed its relation to Heterogemma capitata. The main difference is the markedly acute leaf lobes in Heterogemma patagonica versus the mainly blunt leaf lobes in Heterogemma capitata. Interestingly, Heterogemma patagonica grows in similar habitats as Heterogemma laxa (Lindberg 1875: 539) Konstantinova \& Vilnet (2010: 67) from the Northern Hemisphere. Heterogemma patagonica is retained as an independent species here pending further research on the relations in Heterogemma. 
Heterogemma patagonica (Herzog et Grolle) L.Söderstr. et Váňa, comb. nov.

Basionym:-Lophozia patagonica Herzog et Grolle, Rev. Bryol. Lichénol. 28: 343, 1959 [1960] (Grolle 1960).

Type:-CHILE. Osorno: between San Juan de la Costa and Pucatrihue, 800 m, 1958, Oberdorfer 246 (holotype JE4001765 !).

\section{The identity of Lophozia handelii}

Lophozia handelii was placed in the synonymy of Lophozia guttulata by Bakalin (2003), but not mentioned in his monograph (Bakalin 2005). One of us (JV) has seen rich material of Lophozia handelii from Himalaya and it appears to be a well-developed form of Lophozia guttulata. However, it is in most cases possible to separate it from the latter and we therefore retain the species pending further studies. Lophozia pallida from Yunnan is not much studied, but study of the type shows it to represent large, well developed plants of Lophozia handelii over which it has nomenclatural priority.

Lophozia pallida (Steph.) Grolle, J. Jap. Bot. 39: 174, 1964 (Grolle 1964).

Basionym:-Anastrophyllum pallidum Steph., Bull. Herb. Boissier ser. 2, 1: 1131 (Sp. Hepat. 2: 114), 1901 (Stephani 1901).

Type:-CHINA. Yunnan: Ma-eul-chan, Delavay (lectotype [Bonner 1962: 77] G-53383! [=G-10810!]')

= Lophozia handelii Herzog, Symb. Sin. 5: 14, 1930 (Herzog. 1930), syn. nov. Type:-CHINA. Yunnan: 21.VII.1915, Handel-Mazzetti 1285 (holotype JE!).

\section{Problematic names in Lophozia}

The genus Lophozia s.str. (sensu Konstantinova et al. 2010) includes many problematic taxa and has a chaotic nomenclature as a result of different interpretations of types by different authors. Several molecular studies (De Roo et al. 2007, Vilnet et al. 2010) have also shown that Lophozia ventricosa (Dickson 1790: 14) Dumortier (1835: 14), Lophozia wenzelii (Nees 1836: 58) Stephani (1902a: 35), Lophozia schusterana Schljakov (1975: 320) and Lophozia austro-sibirica Bakalin (2003: 49) (and possibly other taxa) form a complex of closely related, if not conspecific, taxa. On this basis Bakalin (2011) questioned if Lophozia wenzelii can be separated from Lophozia ventricosa at the species level. The type species itself, Lophozia ventricosa, has also been interpreted in different ways, and its use has only recently become stabilized. Schljakov (1980) and others considered the type from Britain to be what is now Lophozia silvicola Buch (1929: 228), a species with biconcentric oil bodies. This is possibly a correct interpretation, since Lophozia silvicola is common in Britain and oil bodies were not studied at the time of description. Thus, Schljakov (1980) used the name Lophozia ventricosa for Lophozia silvicola and Lophozia groenlandica (Nees in Gottsche et al. 1844: 114) Macoun (1902: 19) for Lophozia ventricosa. Konstantinova et al. (1992) argued that Lophozia groenlandica should be rejected and used the next available name, Lophozia confertifolia Schiffner (1905: 47), for Lophozia ventricosa. Grolle \& Long (2000) neotypified Lophozia ventricosa with a specimen where the oil bodies were known (non biconcentric). Thus, the usage of the names Lophozia ventricosa and Lophozia silvicola became fixed. Until recently, Lophozia ventricosa and Lophozia silvicola have often been considered conspecific, sometimes at varietal level. Recent molecular studies (de Roo et al. 2007), however, show that Lophozia silvicola should be treated as a separate species.

Lophozia groenlandica:-As mentioned above, Lophozia groenlandica is a problematic early name, interpreted in different ways. Schuster (1969) used the name for what is now generally known as Lophozia schusterana. Schljakov (1980) considered it a synonym of Lophozia ventricosa as currently defined and used

1. Citation of specimens in G should preferably use the barcode (M. Price, pers. comm.) but for comparability the numbers printed on the specimen, which have often been cited by previous authors, are also given here in square brackets. 
the name for it as he considered Lophozia ventricosa (as currently defined after neotypification) to be a synonym of Lophozia silvicola. Damsholt (1994) selected a lectotype for L. groenlandica and considered it to belong to Lophozia wenzelii. Schljakov (1998), however, accepted it as a good species, and placed Lophozia confertifolia in synonymy of this species, with Lophozia murmanica Kaalaas in Bryhn (1906: 34) and Lophozia heteromorpha Schuster \& Damsholt in Schuster (1969: 507) as possible synonyms (with question mark). This concept (except the synonymy of Lophozia confertifolia) was followed by Grolle \& Long (2000) without question marks. Meinunger (2002), however, considered L. groenlandica a good species, not identical with Lophozia wenzelii or Lophozia confertifolia and Bakalin $(2005,2011)$ regarded it a variety of Lophozia wenzelii. Konstantinova et al. (2010) followed the latter concept and included Lophozia murmanica (with a question mark), but not Lophozia heteromorpha, keeping the latter as an independent species. Although it is one of the oldest names in the complex, we are not using the name here due to the ambiguity of its interpretation. An unambiguous epitype should be selected.

Lophozia murmanica:-Lophozia murmanica has also been interpreted in several ways, especially by Russian authors. Schljakov (1969) and Schljakov (1970) recognized the species but with two different circumscriptions. Later, Schljakov (1980) included his 1969 'species' in Lophozia savicziae Schljakov (1973: 299) and his 1970 'species' (including what he considered to be the type) in his Lophozia groenlandica (= Lophozia ventricosa in the current sense). Schuster (1969) and Grolle \& Long (2000) also included it under Lophozia groenlandica (excl. Lophozia ventricosa) although the concept of Schuster was later referred to Lophozia schusterana by Schljakov (1975). Although briefly discussed by Bakalin (2004), Lophozia murmanica was not mentioned by Bakalin (2005). In both Schljakov (1980) and Grolle \& Long (2000) Lophozia heteromorpha was included as a synonym of Lophozia groenlandica together with Lophozia murmanica.

Lophozia confertifolia:-Another problematic taxon difficult to place is Lophozia confertifolia. It has sometimes been regarded close to Lophozia ventricosa (e.g. Schljakov 1975) and sometimes close to Lophozia wenzelii (e.g. Müller 1954). Konstantinova et al. (1992) used the name for the current Lophozia ventricosa as it had been used in that way for some times (mainly in Russian literature) as they used Lophozia ventricosa for Lophozia silvicola. Grolle \& Long (2000) presented the opinion of Ván̆a that this species is not conspecific with Lophozia wenzelii, but did not say where it should be placed. Meinunger (2002) considered it a good species separated from Lophozia wenzelii by oil-bodies and stem cross section; like Müller (1954) he later (in Meinunger \& Schröder 2007) considered Lophozia confertifolia a form of Lophozia wenzelii. Bakalin (2005) placed it in synonymy of Lophozia wenzelii var. groenlandica (Nees) Bakalin (2001: 213). A lectotype for $L$. confertifolia that clearly can be referred to a specific taxon should be selected among the many syntypes in various herbaria.

Lophozia longiflora:-The name Lophozia longiflora (Nees 1836: 95) Schiffner (1903: 257) has been used for two different taxa during the last 50 years. Pearson (1890) was the first to associate it with Lophozia ventricosa (as Jungermannia ventricosa var. longiflora (Nees) Pearson (1890: 23)). Müller (1954) followed this concept and the taxon was generally considered a variety of Lophozia ventricosa until Schljakov (1981) concluded that all syntypes in Nees' herbarium belong to Lophozia guttulata over which it has nomenclatural priority. The latter concept has generally been followed since then. Meinunger (in Meinunger \& Schröder 2007), however, disagreed with Schljakov (1981) after examination of type material from UPS and STR and kept Lophozia longiflora and Lophozia guttulata as separate species on the basis of the difference in stem cross section. Recently, Bakalin $(2005,2011)$ again used the name in the sense of Müller (1954). A lectotype should be selected for L. longiflora and, if needed, an epitype. Until then we use the name Lophozia guttulata for $L$. longiflora. The following new synonym is proposed: 
Lophozia guttulata (Lindb. et Arnell) A.Evans, Proc. Wash. Acad. Sci. 2: 302, 1900 (Evans 1900).

Basionym:-Jungermannia guttulata Lindb. et Arnell, Kongl. Svenska Vetensk.-Akad. Handl. n.f. 23 (5): 51, 1889 (Lindberg \& Arnell 1889).

= Lophozia porphyroleuca var. viridis Schiffn., Sitzungsber. Deutsch. Naturwiss.-Med. Vereins Böhmen "Lotos" Prag 51: 273, 1903 (Schiffner 1903), syn. nov. Type:-CZECH REPUBLIC. Böhmen: auf faulen Stämmen und Stöcken in den Wäldern bei Salnau im südlichen Böhmerwalde. 900-1100 m, Sept. 1902 lgt V. Schiffner, Hep. eur. exs. no. 150 (lectotype [here designated] FH!).

Conspectus of Lophozia:-The following list includes the taxa accepted here in Lophozia (bold) together with their main recent synonyms. Taxa of uncertain synonymy are placed under all possible accepted taxa, as discussed above, preceded by a question mark.

Lophozia ascendens (Warnst.) R.M.Schust., Bryologist 55: 180, 1952 (Schuster 1952). Basionym: Sphenolobus ascendens Warnst., Hedwigia 57: 63, 1915 [1916] (Warnstorf 1916). Lophozia austro-sibirica Bakalin, Ann. bot. Fenn. 40: 49, 2003 (Bakalin 2003). Lophozia ciliata Damsh., L.Söderstr. et H.Weibull, Lindbergia 25:3, 2000 (Söderström et al. 2000). Lophozia guttulata (Lindb. et Arnell) A.Evans, Proc. Wash. Acad. Sci. 2: 302, 1900 (Evans 1900). Basionym: Jungermannia guttulata Lindb. et Arnell, Kongl. Svenska Vetensk.-Akad. Handl. n.f. 23 (5): 51, 1889 (Lindberg \& Arnell 1889). ?= Lophozia longiflora (Nees) Schiffn. Sitzungsber. Deutsch. Naturwiss.Med. Vereins Böhmen "Lotos" Prag 51: 257, 1903 (Schiffner 1903). Lophozia lacerata N.Kitag., Hikobia 3: 172, 1963 (Kitagawa 1963). Lophozia lantratoviae Bakalin, Ann. Bot. Fenn. 40: 47, 2003 (Bakalin 2003). Lophozia murmanica Kaal., Rep. Second Norweg. Arctic Exped. 11: 34, 1906 (Bryhn 1906). ?= Lophozia groenlandica (Nees) Macoun, Cat. Canad. Pl., Lich. Hepat.: 19, 1902 (Macoun 1902). = Lophozia heteromorpha R.M.Schust. et Damsh., Hepat. Anthocerotae N. Amer. 2: 507, 1969 (Schuster 1969). Lophozia pacifica Bakalin, Bryologist 114: 302, 2011 (Bakalin 2011). Lophozia pallida (Steph.) Grolle, J. Jap. Bot. 39: 14, 1964 (Grolle 1964). Basionym: Anastrophyllum pallidum Steph., Bull. Herb. Boissier ser. 2, 1: 1131 (Spec. Hep. 2: 114), 1901 (Stephani 1901). = Lophozia handelii Herzog, Symb. Sin. 5: 14, 1930 (Herzog. 1930). Lophozia savicziae Schljakov, Novosti Sist. Nizsh. Rast. 10: 299, 1973 (Schljakov 1973). Lophozia schusterana Schljakov, Novosti Sist. Nizsh. Rast. 12: 320, 1975 (Schljakov 1975). Lophozia silvicola H.Buch, Rep. 18. Scand. Naturalist Congr., 228. 1929 (Buch 1929). Lophozia silvicoloides N.Kitag., J. Hattori Bot. Lab. 28: 276, 1965 (Kitagawa 1965). Lophozia subapiculata R.M.Schust. et Damsh., Meddel. Grønland 199 (1): 104, 1974 (Schuster \& Damsholt 1974). Lophozia ventricosa (Dicks.) Dumort., Recueil Observ. Jungerm.: 14, 1835 (Dumortier 1835). Basionym: Jungermannia ventricosa Dicks., Pl. Crypt. Brit. 2: 14, 1790 (Dickson 1790). ?= Lophozia groenlandica (Nees) Macoun, Cat. Canad. Pl., Lich. Hepat.: 19, 1902 (Macoun 1902). ?= Lophozia longiflora (Nees) Schiffn. Sitzungsber. Deutsch. Naturwiss.Med. Vereins Böhmen "Lotos" Prag 51: 257, 1903 (Schiffner 1903). ?= Lophozia confertifolia Schiffn., Österr. Bot. Z. 55: 47, 1905 (Schiffner 1905). Lophozia wenzelii (Nees) Steph., Bull. Herb. Boissier ser. 2, 2: 35 (Spec. Hep. 2 : 135), 1902 (Stephani 1902a). ?= Lophozia groenlandica (Nees) Macoun, Cat. Canad. Pl., Lich. Hepat.: 19, 1902 (Macoun 1902). ?= Lophozia confertifolia Schiffn., Österr. Bot. Z. 55: 47, 1905 (Schiffner 1905).

\section{New synonym and combination in Trilophozia}

Trilophozia quinquedentata (三 Tritomaria quinquedentata (Huds.) Buch (1933: 290)) is a variable species and many varieties and subspecies have been proposed. De Roo et al. (2007) showed that Tritomaria quinquedentata subsp. turgida (Lindb. in Lindberg \& Arnell 1889: 59) Damsholt (1982: 98) cannot molecularly be separated from typical plants although there are some morphological differences. The variety Tritomaria quinquedentata var. grandigemma from Yamal peninsula was described with larger gemmae than usual (22-29 x 16-20 $\mu \mathrm{m})$ as the main differentiation character. As size of gemmae is a variable character, the variety does not merit recognition without other supporting evidence.

Trilophozia quinquedentata (Huds.) Bakalin, Monogr. Lophozia: 34 (Bakalin 2005).

Basionym:- Jungermannia quinquedentata Huds., Fl. Angl. (Hudson): 433, 1762 (Hudson 1762).

= Tritomaria quinquedentata var. grandigemma Potemkin, Arctoa 2: 80, 1993 (Potemkin 1993), syn. nov. Type:RUSSIA. Yamal-Nenets: Paeninsula Jamal, regio ripae sinistrae fl. Laptajaha adjacens $\left(68^{\circ} 20^{\prime}\right.$ lat. bor., $73^{\circ} 15^{\prime}$ long. orient.) 23.VII.1979, O.V. Rebritstaja (holotype LE).

Kitagawa (1963) studied East Asiatic specimens of Tritomaria quinquedentata and distinguished a highly 
papillose variety, var. asymmetrica. Almost simultaneously, Schuster (1966) described the papillose taxon as subsp. papillifera. For now we recognize this taxon at variety level pending further research and the following transfer is done.

Trilophozia quinquedentata var. asymmetrica (Horik.) L.Söderstr. et Váňa, comb. nov.

Basionym:-Lophozia asymmetrica Horik., J. Sci. Hiroshima Univ., Ser. B., Div. 2, Bot. 2: 153, 1934 (Horikawa 1934). Type:-TAIWAN. Tainan: Mt. Morrison (Tâtaka-Mayeyama), Aug. 1932, Y. Horikawa, no. 9140a (holotype HIRO).

$\equiv$ Tritomaria quinquedentata var. asymmetrica (Horik.) N.Kitag., Hikobia 3: 171, 1963 (Kitagawa 1963).

= Jungermannia trilobata Steph., Hedwigia 34: 50, 1895 (Stephani 1895), nom. illeg. (ICN Art. 53.1; hom. illeg. [non L. 1753]). $\equiv$ Sphenolobus trilobatus Steph., Bull. Herb. Boissier ser. 2, 2: 175 (Sp. Hepat. [Stephani] 2: 167), 1902 (Stephani 1902b). 三 Tritomaria quinquedentata subsp. papillifera R.M.Schust., Rev. Bryol. Lichénol. 34: 275, 1966 (Schuster 1966).

\section{New synonym to Tritomaria exsecta}

Sphenolobus striolatus from Taiwan is known only from the type consisting of a small shoot fragment with 12 leaves, one of which is broken. Although gemmae are lacking, the leaf cells agree completely with those of Tritomaria exsecta in size, slightly thickened walls, small to missing trigones and papillose cuticle. The leaves are unequally bilobed, but similar leaves sometimes occur in T. exsecta. We therefore propose the following new synonym.

Tritomaria exsecta (Schmidel. ex Schrad.) Schiffn. ex Loeske, Hedwigia 49: 13, 1909 (Loeske 1909). Basionym:-Jungermannia exsecta Schmidel ex Schrad., Syst. Samml. Crypt. Gew. 2: 5, 1797 (Schrader 1797). = Sphenolobus striolatus Horik., J. Sci. Hiroshima Univ., Ser. B., Div. 2, Bot. 2: 157, 1934 (Horikawa 1934), syn. nov. Type:-TAIWAN. Formosa: Mt. Arisan (Niitakatozanguchi), prov. Tainan, Aug. 1932, leg. Y. Horikawa, n. 9008/b (holotype HIRO 9008!). 三 Anastrophyllum striolatum (Horik.) N.Kitag., Hikobia 3: 171, 1963 (Kitagawa 1963).

\section{Acknowledgements}

We thank Michelle Price (G) and Hans-Joachim Zündorf (JE) for help with information of specimens in their herbaria. The Early Land Plants Today project (ELPT) has been generously supported in part by the Global Biological Information Facility (GBIF) Seed Money Award No.2007-41, activities facilitated in part by funding from the Biodiversity Synthesis Center of the Encyclopedia of Life (BioSynC), partial funding from the National Science Foundation (Award No's 0749762, 1115002), the Warwick Foundation, and the Negaunee Foundation.

\section{References}

Bakalin, V.A. (2001) Notes on Lophozia III. Some taxonomic problems in Lophozia sect. Lophozia. Arctoa 10: $207-218$. Bakalin, V.A. (2003) Notes on Lophozia IV. Some new taxa of Lophozia sensu stricto. Annales Botanici Fennici 40: 4752.

Bakalin, V.A. (2004) Notes on Lophozia V. Comments on sect. Sudeticae, Longidentatae and Savicziae. Arctoa 13: 229240.

Bakalin, V.A. (2005) Monograficzeskaya obrabotka roda Lophozia (Dumort.) Dumort. s. str. [Monograph of the genus Lophozia (Dumort.) Dumort. s. str.]. Nauka, Moscow, 240 pp.

Bakalin, V.A. (2011) Notes on Lophozia VI. Taxonomy and distribution of Lophozia and Schistochilopsis (Lophoziaceae) in North America north of Mexico. Bryologist 114: 298-315. http://dx.doi.org/10.1639/0007-2745.114.2.298

Bonner, C.E.B. (1962) Index Hepaticarum. Pars II. Achiton to Balantiopsis. J. Cramer, Weinheim, 320 pp.

Buch, H. (1929) Eine neue moossystematische Methodik nebst einigen ihrer Resultate und ein neues 
Nomenklatursystem. In: Winge, Ø. (Ed), Beretning om, det 18. Skandinaviske naturforskerm $\phi$ de i Kфbenhavn 26.31. August 1929. København, pp. 225-229.

Buch, H. (1933 “1932”) Vorarbeiten zu einer Lebermoosflora Fenno-scandias. I. Ein Versuch zur Aufspaltung der Gattungen Lophozia Dum. und Sphenolobus Steph. Memoranda societatis pro fauna et flora fennica 8: 282-297.

Bryhn, N. (1906) Bryophyta in itinere polari norvagorum secundo collecta. Report of the Second Norwegian Arctic Expedition in the "Fram," 1898-1902 11: 1-260.

Cavers, F. (1910) The interrelationships of the Bryophyta. New Phytologist 9: 269-304. http://dx.doi.org/10.1111/j.1469-8137.1910.tb05577.x

Damsholt, K. (1982) The perianth of Tritomaria quinquedentata var. turgida (Lindb.) Weim. (Hepaticae). Bryologist 85: 96-98. http://dx.doi.org/10.2307/3243147

Damsholt, K. (1994) On the identity of Jungermannia groenlandica Nees. Journal of the Hattori Botanical Laboratory 75: $173-178$.

De Roo, R.T., Hedderson, T.A. \& Söderström, L. (2007) Molecular insights into the phylogeny of the leafy liverwort family Lophoziaceae Cavers. Taxon 56: 301-314.

Dickson, J. (1790) Plantarum Cryptogamicarum Britanniae, Fasc. 2. G. Nicol, London, 31 pp.

Dickson, J. (1793) Plantarum Cryptogamicarum Britanniae, Fasc. 3. G. Nicol, London, 24 pp.

Dumortier, B.C. (1831) Sylloge Jungermannidearum Europae indigenarum, earum genera et species systematice complectens. J. Casterman, Tournay, $100 \mathrm{pp}$. http://dx.doi.org/10.5962/bhl.title.22343

Dumortier, B.C. (1835) Recueil d'Observations sur les Jungermanniacées. I. Révision des genres. J.-A. Blanquart, Tournay, $27 \mathrm{pp}$. http://dx.doi.org/10.5962/bhl.title.731

Evans, A. (1900) Papers form the Harriman Expedition. 5. Notes on Hepaticae collected in Alaska. Proceedings of the Washington Academy of Sciences 2: 287-314.

Gottsche, C.M., Lindenberg, J.B.G. \& Nees von Esenbeck, S.G. (1844) Synopsis Hepaticarum, fasc. 1. Meissner, Hamburg, pp. 1-144.

Grolle, R. (1960 “1959”) Lophozia (Massula) patagonica Herz. \& Grolle n. sp. Revue Bryologique et Lichénologique 28: 343-345.

Grolle, R. (1964) Miscellanea hepaticologica 11-20. Journal of Japanese Botany 39: 173-178.

Grolle R, Long DG (2000) An annotated check-list of the Hepaticae and Anthocerotae of Europe and Macaronesia. Journal of Bryology 22: 103-140.

He-Nygrén, X.-L., Juslén, A., Ahonen, I., Glenny, D. \& Piippo, S. (2006) Illuminating the evolutionary history of liverworts (Marchantiophyta) - towards a natural classification. Cladistics 22: 1-31. http://dx.doi.org/10.1111/j.1096-0031.2006.00089.x

Herzog, T. (1930) Hepaticae. In: Handel-Mazetti, H.M. (Ed), Symbolae Sinicae, Botanische Ergebnisse der Expedition der Akademie der Wissenschaften in Wien nach Südwest-China. 1914/1918. Part 5. Hepaticae. Springer, Berlin, pp. 1-6.

Hooker, W.J. (1816) British Jungermanniae: being a history and description, with figures, of each species of the genus, and microscopical analysis of the parts, vol. 20-22. Longmans, London, pp. 77-84.

Horikawa, Y. (1934) Monographia Hepaticarum Australi-Japonicarum. Journal of Science of the Hiroshima University: Series B, Division 2 (Botany) 2: 101-325.

Hudson, W. (1762) Flora Anglica. J. Nourse, London, 506 pp.

Husnot, T. (1922) Hepaticologia Gallica. Flore analytique et descriptive des hépatiques de France et des contrées voisines. Cahan, $163 \mathrm{pp}$.

Jørgensen, E. (1934) Norges Levermossor. Bergens Museums Skrifter, n.s. 16: 1-343.

Kitagawa, N. (1963) Lophoziaceae of Taiwan (Formosa). Hikobia 3: 169-176.

Kitagawa, N. (1965) A revision of the family Lophoziaceae of Japan and its adjacent regions. I. Journal of the Hattori Botanical Laboratory 28: 239-291.

Konstantinova, N.A., Bakalin, V.A., Andreeva, E.N., Bezgodov, A.G., Borovichev, E.A., Dulin, M.A. \& Mamontov, Y.S. (2010 “2009”) Checklist of liverworts (Marchantiophyta) of Russia. Arctoa 18: 1-64.

Konstantinova, N.A., Potemkin, A.D. \& Schljakov, R.N. (1992) Checklist of the Hepaticae and Anthocerotae of the former USSR. Arctoa 1: 87-127.

Konstantinova, N.A. \& Vilnet, A.A. (2010 “2009”) New taxa and new combinations in Jungermanniales. Arctoa 18: 6567.

Lindberg, S.O. (1875 “1874”) Hepaticae in Hibernia mense Julii 1873 lectae. Acta Societatis Scientiarum Fennicae 10: 465-559.

Lindberg, S.O. (1876) Sällskapets pro Fauna et Flora fennica sammanträde den 4 november 1876. Helsingfors Dagblad 323 (26 Nov.): 2. 
Lindberg, S.O. \& Arnell, H.W. (1889) Musci Asiae Borealis. Kongliga Svenska Vetenskaps-Akademiens Handlingar, ny följd 23(5): 1-69.

Loeske, L. (1909) Zur Moosflora der Zillertaler Alpen. Hedwigia 49: 1-53.

Macoun, J. (1902) Catalogue of Canadian Plants, Lichenes and Hepaticae. Montréal, 180 pp.

McNeill, J., Barrie, F.R., Buck, W.R., Demoulin, V., Greuter, W., Hawksworth, D.L., Herendeen, P.S., Knapp, S., Marhold, K., Prado, J., Prud'homme van Reine, W.F., Smith, G.F., Wiersema, J.H. \& Turland, N.J. (2012) International Code of Nomenclature for algae, fungi and plants (Melbourne Code) adopted by the Eighteenth International Botanical Congress Melbourne, Australia, July 2011. Regnum Vegetabile 154: 1-240.

McNeill, J., Barrie, F.R., Burdet, H.M., Demoulin, V., Hawksworth, D.L., Marhold, K., Nicolson, D.H., Prado, J., Silva, P.C., Skog, J.E., Wiersema, J.H. \& Turland, N.J. (2006) International Code of Botanical Nomenclature (Vienna Code) adopted by the Seventeenth International Botanical Congress Vienna, Austria, July 2005. Regnum Vegetabile 146: $1-260$.

Meinunger, L. (2002 “2001”) Vorläufige Bemerkungen zu Lophozia groenlandica (Nees) Macoun und nächstverwandte Arten in Deutschland. Verhandlungen des Botanischen Vereins von Berlin und Brandenburg 134: 169-176.

Meinunger, L. \& Schröder, W. (2007) Verbreitungsatlas der Moose Deutschlands. Regensburgische Botanische Gesellschaft, Regensburg, 709 pp.

Migula, W. (1904) Kryptogamen-Flora von Deutschland, Deutsch-Österreich und der Schweiz. Band I. Moose, Lief. 17. Friedrich von Zezschwitz, Berlin, pp. 449-512.

Müller, K. (1913) Die Lebermoose Deutschlands, Oesterreichs und der Schweiz (Dr. L. Rabenhorst's KryptogamenFlora von Deutschland, Oesterreich und der Schweiz, 2nd ed.) 6 Band 17 Lieferung. Eduard Kummer, Leipzig, pp. 145-208.

Müller, K. (1954) Die Lebermoose Europas (Dr. L. Rabenhorst's Kryptogamen-Flora von Deutschland, 3. Aufl.) 6. Band, 4. Lieferung. Akademische Verlagsgesellschaft, Leipzig, pp. 481-640.

Nees von Esenbeck, C.G. (1836) Naturgeschichte der Europäischen Lebermoose mit besonderer Beziehung auf Schlesien und die Oertlichkeiten des Riesengebirgs, vol. 2. Grass, Barth \& Co., Berlin, 500 pp.

Pearson, W.H. (1890) List of Canadian Hepaticae. Geology and Natural History Survey of Canada, ser. 3 1: 1-31.

Potemkin, A.D. (1993) The Hepaticae of the Yamal Peninsula, West Siberian Arctic. Arctoa 2: 57-101.

Reichenbach, H.G.L. (1828) Botanik für Damen, Künstler und Freunde der Pflanzenwelt überhaupt, enthaltend eine Darstellung des Pflanzenreichs, in seiner Metamorphose, eine Anleitung zum Studium der Wissenschaft und zum Anlagen von Herbarien. Leipzig, 528 pp.

Schiffner, V. (1903) Kritische Bemerkungen über die europäischen Lebermoose mit Bezug auf die Exemplare des Exsiccatenwerkes, Hepaticae Europaeae exsiccatae 3 (101-150). Sitzungsberichte des Deutschen Naturwissenschaftlich-Medicinischen Vereins für Böhmen "Lotos" in Prag 51: 213-275.

Schiffner, V. (1905) Bryologische Fragmente XVIII-XXII. Österreichische Botanische Zeitschrift 55: 6-13. http://dx.doi.org/10.1007/BF01791003

Schill, D.B., Long, D.G., Moeller, M. \& Squirrell, J. (2004) Phylogenetic relationships between Lophoziaceae and Scapaniaceae based on chloroplast sequences. Monographs in Systematic Botany from the Missouri Botanical Garden 98: 141-149.

Schäfer-Verwimp, A. (1996) New or interesting records of Brazilian bryophytes, V. Candollea 51: $283-302$.

Schiffner, V.F. (1903) Kritische Bemerkungen über die europäischen Lebermoose mit Bezug auf die Exemplare des Exsiccatenwerkes, Hepaticae Europaeae exsiccatae 3 (101-150). Sitzungsberichte des Deutschen Naturwissenschaftlich-Medicinischen Vereins für Böhmen "Lotos" in Prag 51: 213-275.

Schiffner, V.F. (1942) Kritische Bemerkungen über die europäischen Lebermoose mit Bezug auf die Exemplare des Exsiccatenwerkes, Hepaticae Europaeae exsiccatae 28 (1351-1400). Privately published, Prague, 31 pp.

Schljakov, R.N. (1969) [De positione systematica Lophosiae murmanicae Kaal.]. Novosti sistematiki nizshikh rastenij 6: 241-245.

Schljakov, R.N. (1970) [Sectio nova generis Lophozia Dum. emend. Loeske]. Novosti sistematiki nizshikh rastenij 7: 324-333.

Schljakov, R.N. (1973) [Notulae systematicae in Lophoziaceis Cavers]. Novosti sistematiki nizshikh rastenij 10: 287302.

Schljakov, R.N. (1975) [Additamenta ad floram hepaticarum arcticae URSS]. Novosti sistematiki nizshikh rastenij 12: 318-323.

Schljakov, R.N. (1980) Pechenochnye Mchi Severa SSSR. 3. Nauka, Leningrad, 188 pp.

Schljakov, R.N. (1981) Lophozia longiflora (Hepaticae) - czastyj komponent rastitelnych soobszczestv. Botanicheskii Zhurnal. Moscow \& Leningrad 66: 1197-1205.

Schljakov, R.N. (1998) On the Lophozia groenlandica (Nees) Macoun (Hepaticae). Arctoa 7: 191-196.

Schrader, H.A. (1797) Systematische Sammlung Cryptogamischer Gewächse, Fasc. 2. J. C. Dietrich, Göttingen, pp. 91174.

Schuster, R.M. (1952) Notes on nearctic Hepaticae. V. The status of Lophozia gracillima Buch and its relation to 
Lophozia longidens, Lophozia porphyroleuca and Sphenolobus ascendens. Bryologist 55: 173-185.

Schuster, R.M. (1961) Notes on Nearctic Hepaticae, XVIII. New Lophoziaceae from the arctic archipelago of Canada. Canadian Journal of Botany 39: 965-992. http://dx.doi.org/10.1139/b61-081

Schuster, R.M. (1966) Studies in Lophoziaceae. 1. The genera Anastrophyllum and Sphenolobus and their segregates. 2. Cephalolobus gen. n., Acrolophozia gen. n. and Protomarsupella gen. n. Revue Bryologique et Lichénologique 34: 241-287.

Schuster, R.M. (1969) The Hepaticae and Anthocerotae of North America. vol. II. Columbia University Press, New York, 1062 pp.

Schuster, R.M. (2002) Austral Hepaticae, part II. Beihefte zur Nova Hedwigia 119: 1-606.

Schuster, R.M. \& Engel, J.J. (1975) Austral Hepaticae, IV. Notes on Lophozia subgenus Protolophozia Schust., with diagnosis of a new South American species. Journal of Bryology 8: 465-474.

Schuster, R.M. \& Damsholt, K. (1974) The Hepaticae of West Greenland from the $66^{\circ} \mathrm{N}$ to $72^{\circ}$ N. Meddelelser om Grфnland 199(1): 1-373.

Söderström, L., Weibull, H. \& Damsholt, K. (2000) A new species of Lophozia (subgen. Protolophozia) from Fennoscandia. Lindbergia 25: 3-7.

Söderström, L., De Roo, R. \& Hedderson, T. (2010) Taxonomic novelties resulting from recent reclassification of the Lophoziaceae/Scapaniaceae clade. Phytotaxa 3: 47-53.

Söderström, L., Hagborg, A. \& von Konrat, M. (2012) Notes on Early Land Plants Today. Phytotaxa 65: 41-42.

Stephani, F. (1895) Hepaticarum species novae VII. Hedwigia 34: 43-65.

Stephani, F. (1901) Species Hepaticarum 2. Bulletin de l'Herbier Boissier, série 2 1: 1022-1140.

Stephani, F. (1902a) Species Hepaticarum 2. Bulletin de l'Herbier Boissier, série 2 2: 35-48.

Stephani, F. (1902b) Species Hepaticarum 2. Bulletin de l'Herbier Boissier, série 2 2: 157-179.

Stephani, F. (1908) Species Hepaticarum 3. Bulletin de l'Herbier Boissier, série 2 8(12): 941-966.

Warnstorf, C. (1916 “1915”) Bryophyta nova europaea et exotica. Hedwigia 57: 62-131. 